\title{
Identifikasi Self Esteem Siswa Kelas XTN3 SMK Mudita Singkawang
}

\author{
Devi Susanti ${ }^{1)}$, Iip Istirahayu ${ }^{2)}$ \\ ${ }^{1)}$ Prodi Bimbingan dan Konseling STKIP Singkawang \\ e-mail:devi.dv93@yahoo.com \\ ${ }^{2)}$ Prodi Bimbingan dan Konseling STKIP Singkawang \\ e-mail: iip_istirahayu@yahoo.com
}

\begin{abstract}
Abstrak. Penelitian ini bertujuan untuk mengetahui profil self esteem siswakelas XTN3 SMK MUDITA Singkawang. Jenis penelitian yang digunakan adalah penelitian kuantitatif.Populasi dalam penelitian ini adalah siswa kelas X SMK MUDITA Singkawang. Penelitian ini menggunakan Simple Random Sampling. Sampel dalam penelitian ini adalah36 orang siswakelas XTN3 SMK MUDITA Singkawang.Data dihitung dengan menggunakan penghitungan Zskor. Hasil penelitian menunjukkan bahwa dari 36 orang siswa kelas XTN3, profil siswa dengan kategori tinggi adalah 6 orang (17\%), siswa yangt ergolong dalam kategori sedang sebanyak 24 orang(66\%),dan dalam kategori rendah sebanyak 6 orang (17\%).Saran yang dapat diberikan kepada guru BK adalah dapat menggunakan profil yang ada dalam menentukan materi atau memberikan bimbingan dan layanan yang sesuai dengan kebutuhan siswa, sedangkan untuk peneliti selanjutnya dapat menggunakan hasil penelitian sebagai studi pendahuluan atau referensi dalam penelitiannya.
\end{abstract}

Kata Kunci: Identifikasi, Self Esteem.

\section{Pendahuluan}

Self esteem merupakan kebutuhan mendasar manusia yang sangat kuat serta memberikan konstribusi penting dalam proses kehidupan dan sangat diperlukanuntuk perkembangan yang normal dansehat sehingga memiliki nilai untuk bertahan hidup. Apabila individu memiliki nilai dan keyakinan yang realistis, dan merasa nyaman dengan dirinya sendiri, maka individu akan lebih terbuka dalam memandang kehidupan dan merespon tantangan dan peluang dengan tepat. Hal ini mengilhami individu untuk mengambil kesenangan dan bangga dengan prestasidirinya, dan pada akhirnya mencapai kepuasan.

Self esteem dalah individu yang mampu menerimadiri sendiri sebagaiindividu yang cakap, penuh kebajikan dan berharga [2]. Self esteem dapat menentukan cara seseorang berperilaku di dalam lingkungannya. Individu yang memiliki self esteem yang tinggiakan menerima dan menghargai dirinya sendiri apa adanya, sebaliknya self esteem yang rendah menjadikan individu merasadirinya orang yang tidak berharga, tidak cakap dan tidak berkebajikan.

\section{Metode}

Jenis penelitian yang digunakan adalah penelitian kuantitatif. Populasi dalam penelitian ini adalah siswa kelas X SMK MUDITA Singkawang. Penelitian ini menggunakan Simple Random Sampling. Sampel dalam penelitian ini adalah 36 orang siswa kelas XTN3 SMK
MUDITA Singkawang. Profil self-esteem siswa diperoleh dan dianalisis dengan menggunakan penghitungan $\mathrm{Z}$ skor.

\section{Hasildan Pembahasan}

Hasil perhitungan Zskor, profil self esteem siswa kelas XTN3 SMK Mudita Singkawang di gambarbarkan pada tabel di bawah ini.

Tabel I

Penghitungan Z Skor

\begin{tabular}{llccc}
\hline No & Kategori & Rentang & Frekuensi & Persentase \\
1 & Tinggi & $\mathrm{Z}>1$ & 6 & $17 \%$ \\
2 & Sedang & $-1 \leq \mathrm{Z} \leq 1$ & 24 & $66 \%$ \\
& Rendah & $\mathrm{Z}<-1$ & 6 & $17 \%$ \\
3 & Total & & & $100 \%$ \\
\hline
\end{tabular}

(Furqon, 2011:140)

Berdasarkan tabel 3.1 diatas, tampak bahwa secara keseluruhan analisis penyebaran angket self esteem oleh guru pembimbing kepada siswa kelas XTN3 di SMK MUDITA Singkawang.

Siswa dengan kategori tinggi sebanyak 17\% artinya 6 orang siswa mampu menghargai dirinya yang terlihat dari prilaku menjaga kehormatan diri, mampu memaafkan diri, 
mampu bertanggungjawab, bersemangat dalam menjalani hidup, bersyukur atas hidup sendiri, mampu menghargai orang lain dan menciptakan kenyamanan dalam menjalin hubungan yang baik dengan orang lain.

Siswa dengan kategori sedang sebanyak $67 \%$ artinya 24 orang siswa cukup mampu menghargai dirinya terlihat dari prilaku cukup mampu menghormati diri sendiri, memaafkan diri sendiri, dan menghargai diri sendiri. Selain itu, siswa juga cukup mampu menjadi pribadi yang bertanggungjawab, berantusias dalam menjalani kehidupannya, dan selalu bersyukur atas hidup yang dijalaninya. Selanjutnya, siswa juga mampu menghargai orang lain, mampu menciptakan komunikasi yang efektif dan mampu membuat orang lain merasa nyaman.

Siswa dengan kategori rendah sebanyak $17 \%$, artinya 6 orang siswa kurang mampu menghargai dirinya terlihat dari prilaku tidak menghormati dirinya sendiri, sulit memaafkan diri sendiri, tidak terlalu antusias dalam menjalani hidupnya sendiri, tidak mampu berkomunikasi dengan efektif, dan sulit menjalin hubungan yang baik dengan orang lain.

\section{Simpulan dan Saran}

Hasil penelitian menunjukkan bahwa dari 36 orang siswa kelas XTN3, profil siswa dengan kategori tinggi adalah 6 orang (17\%), siswa yang tergolong dalam kategori sedang sebanyak 24 orang $(66 \%)$, dan dalam kategori rendah sebanyak 6 orang $(17 \%)$.

Saran yang dapat diberikan kepada guru BK adalah dapat menggunakan profil yang ada dalam menentukan materi atau memberikan bimbingan dan layanan yang sesuai dengan kebutuhan siswa, sedangkan untuk peneliti selanjutnya dapat menggunakan hasil penelitian sebagai studi pendahuluan atau referensi dalam penelitiannya.

\section{Referensi}

[1] Furqon. (2011). Statistika Penerapan Untuk Penelitian. Bandung: Alfabeta.

[2] Istirahayu, Iip \& Yusuf, Syamsu (2015).Identification the Quantity of Student'The Effectiveness of Theistic Spiritual Counseling in Improving Students' Intrapersonal Competency. Vol. 2, 336-342. 